Research Article / Araştırma Makalesi

\title{
Mesleki Gelişim Etkinlikleri Ölçeğinin Uyarlanması: Geçerlik ve Güvenirlik Çalışması"
}

\author{
Adaptation of Professional Development Activities Scale: Validity and Reliability Study
}

\author{
Mehmet Eroğlu $^{* *}$ - Ramazan Özbek ${ }^{* * *}$
}

\begin{abstract}
The aim of the study is to adapt the scale of professional development activities developed by Kwakman (1999) and updated by Dijkstra (2009) into Turkish. In the first stage of the adaptation studies of the scale, the original form of which is 3 dimensions and 40 items, linguistic and cultural equivalence study was conducted. Since 5 items in the scale were determined not to be suitable for cultural structure according to expert opinions, a 35-item form was created to conduct. In order to collect the data of the research, ethical compliance report (Date: 03/08/2017, Decision number: 2017/3/2) was obtained from Inonu University Scientific Research and Publication Ethics Board and research permission (Date: 28/03/2017, Number: 79137285-604.01.01-E.4143261) was obtained from Elazig Provincial Directorate of National Education. The data is collected from 748 teachers for the validity and reliability studies of the scale. In the exploratory factor analysis (EFA), 4 dimension scale consisting of 22 items with factor loads between .80 and .49 explaining $59.37 \%$ of the total variance was obtained. The factors were named as collaboration activities, update activities, sharing activities and reflection activities considering the original version of the scale. In the confirmatory factor analysis $(\mathrm{CFA}), \chi^{2} / \mathrm{Df}=2.30, \mathrm{TLI}=.95, \mathrm{CFI}=.95, \mathrm{RMSEA}=.048, \mathrm{SRMR}=.042$ fit index values is obtained. These results showed that the scale has structural validity. Cronbach Alpha internal consistency coefficient is calculated for reliability analysis of the scale. Cronbach Alpha internal consistency coefficients is calculated as .88 for collaboration activities, .84 for update activities, .88 for sharing activities, .70 for reflective activities, and .92 for the overall scale. As a result, it is determined that the scale of professional development activities, which can measure the participation of teachers in professional development, is a valid and reliable measurement tool consisting of 22 items in 4-point Likert type.
\end{abstract}

Structured Abstract: Introduction: Student achievement is accepted as one of the basic indicators of quality in education today (Akgündüz et al., 2015). For this reason, studies on increasing the quality of education in recent years focus on increasing student achievement. Although there are many factors that affect student achievement in education, it is emphasized that teacher quality is the most important factor affecting student achievement (Adesina et al., 2016; Caena, 2011; OECD, 2005, 2011). The quality of the teacher is particularly

\footnotetext{
* $\mathrm{Bu}$ araştırma "öğretmenlerin mesleki gelişime katılımlarıyla, mesleki gelişime yönelik tutumları, kendi kendine öğrenmeye hazır bulunuşlukları ve destekleyici okul özellikleri arasındaki ilişkinin incelenmesi" adlı doktora tezinin bir bölümüdür.

*** Dr., Fırat Üniversitesi, Eğitim Fakültesi, Eğitim Bilimleri Bölümü

Dr., Firat University, Faculty of Education, Department of Educational Science

ORCID 0000-0003-1906-5835

mehmeteroglu@ firat.edu.tr

**** Doç. Dr., İnönü Üniversitesi, Eğitim Fakültesi, Eğitim Bilimleri Bölümü

Assoc. Prof., Dr. Inonu University, Faculty of Education, Department of Educational Science

ORCID 0000-0002-6228-1624

ramazan.ozbek@inonu.edu.tr

Cite as/ Atıf: Eroğlu, M. \& Özbek, R. (2020). Mesleki gelişim etkinlikleri ölçeğinin uyarlanması: geçerlik ve güvenirlik çalışması. Turkish Studies - Education, 15(4), 2611-2628. https://dx.doi.org/10.47423/TurkishStudies.42998

Received/Geliş: 18 June/Haziran 2020

Accepted/Kabul: 27 August/Ağustos 2020

Checked by plagiarism software

Copyright (C) INTAC LTD, Turkey

Published/Yayın: 30 August/Ağustos 2020

CC BY-NC 4.0
} 
relevant to professional development (Hamdan and Lai, 2015). Because professional development is a process that increases the quality of teachers and contributes to students' better learning and achievement (Blank and De Las Alas, 2009; Garet et al., 2001; Isabel, 2010). Therefore, professional development forms the basis of educational reforms, practices and policies that aim to increase the quality of education (Sandholtz and Ringstaff, 2013). Professional development of teachers is directly related to the richness of their professional experience and the effective professional development activities they participate in (Chang et al., 2011). Because it is known that teachers' participation in professional development positively affects student achievement. For this reason, teachers should participate in professional development activities in order to improve themselves and to do their profession effectively. Therefore, it is important to measure teachers' participation in professional development (Özdemir, 2016). However, there are few measurement tools in the literature that measure teachers' participation in professional development. Moreover, it has been determined that there are a limited number of measurement tools in the Turkish Education System that measure teachers' participation in professional development (Eroğlu and Özbek, 2018; Gümüş et al., 2018). Therefore, measurement tools are needed to measure teachers' participation in professional development.

Aim of The Study: The aim of the study is to adapt the scale of professional development activities developed by Kwakman (1999) and updated by Dijkstra (2009) into Turkish.

Method: The research is a scale adaptation study. In the first stage of the adaptation study of the scale, the original form of which is 3 dimensions and 40 items, linguistic and cultural equivalence study was conducted. Since 5 items in the scale were determined not to be suitable for cultural structure according to expert opinions, a 35-item form was created to conduct. In order to collect the data of the research, ethical compliance report (Date: 03/08/2017, Decision number: 2017/3/2) was obtained from Inonu University Scientific Research and Publication Ethics Board and research permission (Date: 28/03/2017, Number: 79137285-604.01.01-E.4143261) was obtained from Elazığ Provincial Directorate of National Education. For the validity and reliability study of the scale, data were collected from 748 teachers working in secondary schools and high schools in Elazig city center in 2017. Exploratory factor analysis (EFA) and confirmatory factor analysis (DFA) were carried out to test the construct validity of the scale. Cronbach Alpha internal consistency coefficient and item-total correlations were calculated to determine the reliability of the scale.

Findings, Discussion and Results: Before performing EFA, Kaiser-Meyer-Olkin (KMO) coefficient was calculated as .924, Bartlett's test of sphericity $(5810.015 ; \mathrm{p}=.000)$ was found to be significant. In EFA, 4 dimension scale consisting of 22 items with factor loads between .80 and .49 explaining $59.37 \%$ of the total variance was obtained. The factors were named as collaboration activities, update activities, sharing activities and reflection activities considering the original version of the scale. In the confirmatory factor analysis (CFA), $\chi^{2} / \mathrm{Df}=2.30, \mathrm{TLI}=.95, \mathrm{CFI}=.95, \mathrm{RMSEA}=.048, \mathrm{SRMR}=.042$ fit index values is obtained. These results showed that the scale has structural validity. Cronbach Alpha internal consistency coefficient is calculated for reliability analysis of the scale. Cronbach Alpha internal consistency coefficients is calculated as .88 for collaboration activities, .84 for update activities, .88 for sharing activities, .70 for reflective activities, and .92 for the overall scale.

Although the first form of the scale, which was developed qualitatively by Kwakman (1999), had 4 factors, then the form that was piloted and quantified by Dijkstra (2009) has 3 factors. These differences may arise from the difference in the approaches used in the development of the measurement tool and the difference between the application dates. However, in this study in which the scale was adapted to a different culture, a structure with 4 factors emerged. It is seen that a structure similar to the factor structure of this adapted scale also appears in the Teacher Professional Learning Scale developed by Liu, Hallinger and Feng (2016) and adapted to Turkish by Gümüss et al. (2018). Also it has been determined that the dimensions of these two measurement tools are similar in Turkish culture.

As a result, it is determined that the scale of professional development activities, which can measure the participation of teachers in professional development, is a valid and reliable measurement tool consisting of 22 items in 4-point Likert type. The minimum score that can be obtained from the scale is 22 , and the maximum score is 88 . The high score to be obtained through scoring the scale indicates that teachers' participation in professional development is high. However, in order to be able to say that the level of participation in professional development is high, it is expected that the scores obtained for all dimensions will be high. Because each dimension provides the development of different professional knowledge and skills.

Turkish Studies - Education, 15(4) 
Limitations and Further Studies: The adapted measurement tool has some limitations. One of these limitations is the limited number of items that emphasize today's digital learning resources and methods in professional development. However, this measurement tool can be used in determining the participation of teachers in professional development, determining the relationships between participation in professional development and teacher characteristics and student achievement. In addition, it allows to examine the type of professional development activity and its effect on teacher practices and student achievement.

Keywords: Curriculum and Instruction, Professional Development of Teachers, Professional Development Activities, Participation in Professional Development, Scale Adaptation

Öz: Bu araştırmanın amacı Kwakman (1999) tarafından geliştirilen ve Dijkstra (2009) tarafından güncellenen mesleki gelişim etkinlikleri ölçeğinin Türkçeye uyarlama çalışmasının yapılmasıdır. Orijinal formu 3 boyut ve 40 madde olan ölçeğin uyarlama çalışmalarının ilk aşamasında dilsel ve kültürel eşdeğerlik çalışması yapılmıştır. Ölçekteki 5 madde kültürel yapıya uygun olmadığından uzman görüşüyle çıkarılarak 35 maddelik uygulama formu oluşturulmuştur. Araş̧ırmanın verilerini toplamak için İnönü Üniversitesi Bilimsel Araştırma ve Yayın Etiği Kurulu'ndan etik uygunluk raporu (Tarih: 03/08/2017, Karar no: 2017/3/2), Elazığ İl Milli Eğitim Müdürlüğü'nden araştırma izni (Tarih: 28/03/2017, Sayı: 79137285-604.01.01-E.4143261) alınmıştır. Ölçeğin geçerlik ve güvenirlik çalışmaları için 748 öğretmenden veri toplanmıştır. Yapılan açımlayıcı faktör analizinde, toplam varyansın \%59.37' sini açıklayan faktör yükleri .80 ile .49 arasında olan 22 maddeden oluşan 4 boyutlu ölçek elde edilmiştir. Yapılan doğrulayıcı faktör analizinde iyi uyumu gösteren $\chi^{2} / s d=2.30$, $\mathrm{TLI}=.95, \mathrm{CFI}=.95, \mathrm{RMSEA}=.048, \mathrm{SRMR}=.042$ uyum indeksi değerleri elde edilmiş̧tir. Oluşan faktörler ölçeğin orijinal hali dikkate alınarak işbirliği etkinlikleri, güncelleme etkinlikleri, paylaşım etkinlikleri ve yansıtma etkinlikleri olarak adlandırılmıştır. Bu sonuçlar ölçme aracının yapısal geçerliğinin olduğunu ortaya koymuştur. Ölçeğin güvenirlik analizleri için Cronbach Alpha iç tutarlılık katsayısı hesaplanmıştır. Cronbach Alpha iç tutarlılık katsayıları, işbirliği etkinlikleri için .88, güncelleme etkinlikleri için .84, paylaşım etkinlikleri için .88, yansıtıcı etkinlikler için, .70 iken ölçeğin geneli için .92 olarak hesaplanmıştır. Sonuç olarak uyarlaması yapılan öğretmenlerin mesleki gelişime katılımlarını ölçebilecek mesleki gelişim etkinlikleri ölçeği, 4'lü likert tipinde 22 maddeden oluşan geçerli ve güvenilir bir ölçme aracı olduğu belirlenmiştir.

Anahtar Kelimeler: Eğitim Programları ve Öğretim, Öğretmenlerin Mesleki Gelişimi, Mesleki Gelişim Etkinlikleri, Mesleki Gelişime Katılım, Ölçek Uyarlama

\section{Giriş}

Bilim ve teknolojide hızlı değişimlerin yaşandığı çağımızda toplumların gelişmişliğinin en önemli göstergelerinin başında vatandaşlarına verdikleri eğitimin kalitesi gelmektedir. Bu nedenle eğitimin kalitesinin artırılmasına yönelik araştırmalar, uygulamalar, reformlar vs. en çok üzerinde durulan konulardır. Bu durumun önemli sebeplerinden biri eğitimde kalite konusunun toplumdaki herkesi ilgilendiren bir konu olmasıdır. Ayrıca kaliteli eğitim doğası gereği çok değişkenli bir yapıdır. Bu bağlamda değerlendirildiğinde neyin eğitimi kaliteli yaptığına ilişkin birçok bakış açısı ve değişkenden bahsetmek mümkündür. Ancak öğrenci başarısı günümüzde eğitimde kalitenin temel göstergelerinden biri olarak kabul edilmektedir (Akgündüz vd., 2015). Bu nedenle son y1llarda eğitimde kalitenin artırılmasına ilişkin çalışmalar öğrenci başarısının artırılmasına odaklanmaktadır. Eğitimde öğrencinin başarısını etkileyen birçok faktör olmasına rağmen öğretmen kalitesinin öğrencinin başarısını etkileyen en önemli faktör olduğu vurgulanmaktadır (Adesina vd., 2016; Caena, 2011; Nye vd., 2004; OECD, 2005, 2011; Sass vd., 2012). Öğretmenin kalitesi ise mesleğe girişteki kalitesi ve hizmetindeki yetkinliği ile ilişkili olmakla birlikte mesleki bilgi ve becerilerini geliştirmesini sağlayan mesleki gelişimle ilgilidir (Hamdan ve Lai, 2015; Kaçan, 2004; Özer, 2005).

Mesleki gelişim, öğretmenlerin mesleki yeteneklerini geliştirmeleri için meslek yaşamları boyunca katıldıkları etkinlikleri vurgulayan bir süreçtir (Bubb ve Early, 2007; Craft, 2002; Day ve Sach 2005; Wells, 2014). İlgili alanyazında mesleki gelişim kavramının yerine benzer anlamda olan öğretmen gelişimi, hizmet içi eğitim, personel gelişimi, sürekli mesleki gelişim, sürekli eğitim 
kavramları da kullanılabilmektedir (Wermke, 2013). Mesleki gelişim öğretmenlerin niteliğini artırarak öğrencilerin daha iyi öğrenmesine ve başarısına katkıda bulunan bir süreçtir (Blank ve De Las Alas, 2009; Garet vd., 2001; Isabel, 2010). Dolayısıyla mesleki gelişimin nihayi amacı öğretmenlerin mesleki bilgi ve becerilerini geliştirerek öğrenci başarısını artırmaktır (Day \& Sach, 2005; Guskey, 2000; Reese, 2010). Bu nedenle mesleki gelişim, eğitimin kalitesini arttırmay1 amaçlayan eğitim reformlarının, uygulamalarının ve politikalarının temelini oluşturmaktadır (Sandholtz ve Ringstaff, 2013; Seferoğlu, 2001; Smith ve Desimone, 2003).

Öğretmenlik profesyonel bir meslek olduğundan öğretmenlerin mesleki bilgi ve becerilerini sürekli olarak güncellemeleri gerekmektedir (Baştürk, 2012; Chang vd., 2011; Uştu vd., 2016). Mesleki gelişimle öğretmenlerin mesleki bilgi ve becerilerini artırarak onlara yeni anlayışlar kazandırmayı, öğrencilerinin iyi öğrenmesine katkı sağlayarak mesleklerini etkili bir şekilde sürdürmesi amaçlanmaktadır (Özdemir, 2016). Bu bağlamda değerlendirildiğinde öğretmenlerin mesleki gelişimi mesleki deneyimlerinin zenginliği ve katıldıkları katıldıkları etkili mesleki gelişim etkinlikleriyle doğrudan ilişkilidir (Chang vd., 2011). Bu nedenle öğretmenlerin kendilerini geliştirmeleri ve mesleklerini etkin bir şekilde yapabilmeleri için mesleki gelişim etkinliklerine katılmaları gerekmektedir (Özdemir, 2016). Öğretmenler bu etkinlikler sayesinde mesleki görevlerini daha iyi ve etkili bir şekilde yerine getirebilirler. Yani öğretmenlerin mesleki gelişimin sağlanmasında mesleki gelişim etkinlikleri çok önemli rol oynar (Garet vd., 2001; İlğan, 2013; Kwakman, 2003).

Alanyazında araştırmacılar tarafindan birçok mesleki gelişim etkinliği tanımlanmıştır. Guskey (2000), önde gelen mesleki gelişim etkinliklerini eğitimler, gözlem/değerlendirme, gelişim süreçlerine katılma, çalışma grupları, eylem araştırması, bireysel etkinlikler, mentörlük olarak tanımlamıştır. Akiba (2012) da mesleki gelişim etkinliklerini mesleki gelişim programları, öğretmen işbirliği, üniversite kursları, konferanslar, mentorluk/koçluk, informal iletişimler, bireysel öğrenme aktiviteleri olarak tanımlamıştır. Mesleki gelişim etkinliklerine ilişkin benzer tanımlamaları Scales ve arkadaşları (2011) ve Mizell (2010) da yapmıştır. Bazı araştırmacılar ise mesleki gelişim etkinliklerini temel özelliklerine göre sinıflamışlardır. Lieberman (1995) mesleki gelişim etkinliklerini doğrudan öğretim, okulda öğrenme ve okul dışı olarak sınıflamıştır. Bazı çalışmalarda ise mesleki gelişim etkinlikleri geleneksel, reform temelli ve informal mesleki gelişim etkinlikleri olarak sınıflandırılmıştır (Gümüş, 2013).

Öğretmenlerin mesleki gelişme katılımlarının öğrenci başarısını olumlu etkilediği bilinmektedir (Blank \& De Las Alas, 2009; Garet vd., 2001; Isabel, 2010). Bu nedenle mesleki gelişim etkinliklerinin belirlenmiş veya sınıflanmış olması yeterli değildir. Çünkü mesleki gelişim sistematik bir süreçtir ve ölçülmesi gerekir (Guskey, 2000). Bu nedenle öğretmenlerin mesleki gelişime katılımlarının ölçülmesi önemlidir. Ancak literatürde öğretmenlerin mesleki gelişime katılımı ölçen az sayıda ölçme aracı vardır (Eroğlu ve Özbek, 2018; Gümüş vd., 2018; Kwakman, 2003; Liu vd., 2016). Öğretmenlerin mesleki gelişime katılımlarını ölçen alan yazındaki az sayıda ölçme aracından birisi Kwakman (1999) tarafından geliştirilen Dijsktra (2009) tarafından güncellenen mesleki gelişim etkinlikleri ölçeğidir. Kwakman (1999) ilgili alanyazına ve yaptığı nitel araştırmaya dayalı olarak geliştirdiği ölçme aracı mesleki gelişim etkinliklerini 4 boyutta sınıflandırmıştır. Bu kategoriler mesleki okuma, deneyimleme, yansıtma ve işbirliği boyutlarıdır. Daha sonra Dijkstra (2009) tarafından bu güncellenen ölçme aracı güncelleme, yansıtma ve işbirliği olmak üzere 3 boyutludur. Bu ölçme aracı mesleki gelişim mesleki gelişimin güncelleme (DarlingHammond, 2000; King ve Newmann, 2000), yansitma (Korthagen, 2017; Schön, 1987; Vermunt \& Endedijk, 2011) ve işbirliği (Kwakman, 2003; Penuel, Fishman, Yamaguchi, \& Gallagher, 2007) gibi temel bileşenlerini içermesinden ve bir çok önemli çalışmada (de vries, vd 2013a; de vries vd., 2013b; Kwakman, 2003) kullanılmış olmasından dolayı önemlidir. 
Türkiye bağlamında değerlendirildiğinde öğretmenlerin mesleki gelişime katılımlarını ölçen çok az sayıda ölçme aracı bulunmaktadır (Eroğlu ve Özbek, 2018; Gümüş vd., 2018). Oysa diğer bir çok ülkede olduğu gibi Türkiye'de de öğretmenlerin eğitimi ve mesleki gelişimi nitelik ve nicelik açısından yetersizlikler barındırmaktadır (Bellibaş ve Gümüş, 2016; Bümen vd., 2012; Elçiçek ve Yaşar, 2016; İlğan, 2013; İzci ve Eroğlu, 2016; Yaylac1, 2013). Ancak son yıllarda bu yetersizlikleri gidermek için özellikle öğretmenlerin mesleki gelişimine yönelik yeni uygulamalar öne çıkmaktadır. Okul temelli mesleki gelişim, uzaktan eğitimle mesleki gelişim bunlardan bazılarıdır (Kaya ve Kartallıŏlu, 2010). Ayrıca MEB' in 2023 eğitim vizyonunda öğretmenlerin mesleki gelişimi özellikle vurgulanmaktadır (MEB, 2017). Dolayısıyla bu süreçlerde öğretmenlerin mesleki gelişime katılımlarını ölçecek kültüre uygun ölçme araçlarının bulunması oldukça gereklidir. Öğretmenlerin mesleki gelişimlerinin sistematik olarak yürütülmesinde ve dönüt sağlanmasında bu ölçme araçları oldukça önemlidir.

\section{Araştırmanın amacı}

Bu araştırmanın amacı Kwakman (1999) tarafından geliştirilen ve Dijkstra (2009) tarafından güncellenen mesleki gelişim etkinlikleri ölçeğinin Türk kültürüne uyarlanmasıdır.

\section{Yöntem}

Bu araştırma bir ölçek uyarlama çalışmasıdır. Bu araştırma kapsamında Kwakman (1999) tarafından geliştirilen ve Dijkstra (2009) tarafından güncellenen mesleki gelişim etkinlikleri ölçeğinin Türk kültürüne uyarlanması amaçlanmaktadır.

\section{Uyarlama İşlemleri}

Kwakman (1999) tarafından nitel araştırmayla geliştirilen, Dijkstra (2009) tarafından güncellenen öğretmenlerin mesleki gelişim etkinlikleri ölçeği 3 boyut ve 40 maddeden oluşmaktadır. Dörtlü likert tipindeki ölçekte güncelleme etkinlikleri (11 madde), yansıtıcı etkinlikler (13 madde), işbirlikçi etkinlikler (16 madde) boyutları yer almaktadır. Yazarlardan Kitty Kwakman'a e-posta yoluyla ulaşılarak ölçeğin uyarlanması için gerekli izin alınmıştır. Bunun yanında geliştirme ve güncellemeye ilişkin çalışmalar Hollandaca olduğundan dille ilgili sorunlar yaşanmıştır. Ölçeğin güncel formu için Kwakman'ın yönlendirmesiyle de Vries'e ulaşılmış de Vries ve arkadaşlarının (2013a) çalışmasında kullanıldığı şekliyle ölçek alınmıştır.

Dilsel Eşdeğerlik Çalışması: Uyarlama çalışması kapsamında öncelikle dilsel eşdeğerlik çalışması yapılmıştır. Dilsel eşdeğerlik çalışmasında, ölçek maddelerinin Türkçe 'ye çevrilmesinde bir hata olup olmadığını ve maddelerin çevirilen kültürdeki anlamlılığını kontrol etmek için yapılmıştır. Uyarlama yapılırken Türkçenin dil özellikleri, kültürel özellikler ve örneklemin özellikleri dikkate alınmıştır. Orijinal ölçeğin 40 maddelik İngilizce formu Türkçeye çevrilmiştir. Çeviri surecinde öncelikle, ölçekte yer alan maddeler, Fırat Üniversitesi, Yabancı Diller Bölümünde, İngilizce Anabilim Dalındaki 2 Okutman ve Eğitim Fakültesinde çalışan öğretmen eğitiminde uzman 2 öğretim üyesi (1 Kimya Eğitimi, 1 Fizik Eğitimi) tarafından Türkçeye çevrilmiştir. Çeviriciler birbirinden etkilenmemek için çevirme işlemini birbirinden bağımsız bir şekilde yapmışlardır. Daha sonra 1 okutman, öğretim üyesi ve araştırmacılar bir araya gelerek yapılan Türkçe çevirileri karşılaştırmalı olarak incelemişlerdir. Bu incelemeden sürecinin sonunda bütün katılımcıların görüş birliği sağladığ 1 tek çeviri formu oluşturulmuştur. Bu süreç sonunda 5 madde kültürel olarak anlamlılık ifade etmediğinden çıkarılmıştır. Bu maddeler tablo’ da görülmektedir. 
Tablo 1: Mesleki Gelişim Etkinlikleri Ölçeğinin Dilsel Eşdeğerlik Çalışmalarında Atılan Maddeler Atılan Maddeler

Öğretim becerimi geliştirmek için derslerimin video kayıtlarını incelerim.

Meslektaşlarımdan bir şeyler öğrenmek için derslerini ziyaret ederim/izlerim.

Öğretmenliğimle ilgili dönüt vermeleri için meslektaşlarımdan bazı derslerimi izlemelerini isterim.

Meslektaşlarımla birlikte ders veririz(takım öğretimi)

Meslektaşlarımla birlikte program geliştiririz

Tablo 1' de belirtilen maddeler bazı gerekçeler dikkate alınarak formdan çıkarılmıștır. Derslerin video kaydının alınabilmesi öğretmenlerin isteğine bağlı bir durum değildir. Bu nedenle bir takım resmi izinlerin alınmış olması gerekmektedir. Bu durum derslerin video kaydının alınmasını zorlaştırmaktadır. Türkiyede öğretmenlerin birbirinin mesleki gelişimini sağlayacak destekleyici ve işbirlikçi bir yapı yeterince gelişmediğinden (Bümen vd., 2012) ders ziyareti veya meslektaşların dersinin izlenmesi pek karşılaşılan bir durum değildir. Takım öğretiminin ise öğretmenler arası yüksek derecede işbirliğini gerektiren bir etkinlik olduğu düşünüldüğünde Türk Eğitim Sisteminde bu etkinliklerin uygulanmasının oldukça zor olduğu kolayca anlaşılabilir. Çünkü Türk Eğitim Sisteminde öğretmenler arasındaki mesleki işbirliği istenilen düzeyde değildir (Eroğlu, 2019). Ayrıca Türk eğitim sisteminde programlar merkezi olarak hazırlandığından (Demirel, 2007) dolayı öğretmenlerin program geliştirmesi söz konusu değildir. Araştırmacılar ve öğretmen eğitiminde uzman 2 öğretim üyesinin (1 Kimya Eğitimi, 1 Fizik Eğitimi) görüşleri doğrultusunda bu gerekçeler dikkate alınarak tablo 1' de belirtilen maddeler ölçekten çıkarılmıştır. Daha sonra Türkçe dilinde uzman bir kişiden çevirinin dil bilimi açısından Türkçeye uygunluğu konusunda görüş alınmıştır. Ayrıca iki ölçme ve değerlendirme uzmanının ölçme aracının biçimi ve madde yapısının uygunluğuna ilişkin görüşleri alınmıştır. Bu görüşler doğrultusunda gerekli düzeltmeler yapılarak 35 maddelik uygulama formu oluşturulmuştur.

\section{Örneklem ve Verilerin Toplanması}

Araştırmanın örneklemini 2017 yılında Elazığ il merkezinde yer alan ortaokul ve liselerde çalışan branş öğretmenleri oluşturmaktadır. Çalışmada örneklemdeki tüm öğretmenlere ulaşılması amaçlanmıştır. Tez çalışması kapsamında olan araştırmanın verilerini toplamak için öncelikle İnönü Üniversitesi Bilimsel Araştırma ve Yayın Etiği Kurulu'na başvurularak ölçme aracının uygulama formu için etik uygunluk raporu (Tarih: 03/08/2017, Karar no: 2017/3/2) alınmıştır. Araştırma örneklemindeki öğretmenlerden veri toplamak için etik uygunluk raporunu da içeren belgelerle Elazı ̆̆ İl Milli Eğitim Müdürlüğü'ne araştırma izni için başvurulmuştur. Gerekli araştırma izni Elazığ İl Milli Eğitim Müdürlüğü'nden alımıştır (Tarih: 28/03/2017, Sayı: 79137285-604.01.01E.4143261). Veriler araştırmacılar tarafindan toplanmıştır. Veri toplama sürecinde araştırmaya ilişkin katılımcılar araştırmacılar tarafindan bilgilendirilmiştir. Araştırmaya katılımda gönüllülük esas alınmıştır. Araştırma verileri, farklı öğretmenlerden oluşan 2 gruptan farklı zamanlarda toplanmiştır.

Birinci çalışma grubundan elde edilen veriler kullanılarak ölçeğin açımlayıcı faktör analizi (AFA), madde analizi ve Cronbach Alpha iç tutarlılık katsayısı hesabı yapılmıştır. Bu kapsamda branş öğretmenlerinden toplam 182 adet veri toplanmıştır. Araştırmaya katılan öğretmenlerin 90' 1 (\%49) erkek, 92' si (\%51) kadındır. Öğretmenlerin 96' s1 (\%53) ortaokulda, 86' s1 (\%47) ise liselerde çalışmaktadır. Öğretmenlerin 39' u (\%21) 1-5 yı1, 34' ü (\%19) 6-10 yıl, 30' u (\%17) 11-15 y11, 28' i (\%15) 16-20 yı1, 51' i (\%28) 20 yıl üzeri kıdeme sahiptir. Öğretmenlerin branş dağılımları 26' s1 (\%14) Türkçe, 33' ü (\%18) matematik, 28' i (\%15) fen bilimleri, 28' i (\%15) sosyal bilimler, 20' si 
(\%11) İngilizce, 9' u (\%5) spor-sanat, , 9' u (\%5) meslek dersleri, 17' si (\%9) din kültürü ve ahlak bilgisi, 10' u (\%6) Bilişim teknolojileri ve 2' si \%1'i rehberlik şeklindedir.

İkinci çalışma grubunun verileri kullanılarak ölçeğin Doğrulayıcı Faktör Analizi (DFA) yapılmıştır. Ölçeğe DFA yapmak için veriler 566 branş öğretmeninden elde edilmiştir. Araştırmaya katılan öğretmenlerin 295' i (\%52) erkek, 271' i (\%48) kadındır. Öğretmenlerin 284' ü (\%51) ortaokulda, 282' si (\%49) ise liselerde çalışmaktadır. Öğretmenlerin 110' u (\%19) 1-5 yı1, 106' s1 (\%19) 6-10 y11, 106' s1 (\%19) 11-15 y11, 115' i (\%20) 16-20 y11, 129' u (\%23) 20 y1l üzeri kıdeme sahiptir. Öğretmenlerin branş dağılımları 105' i (\%19) Türkçe, 86' s1 (\%15) matematik, 76' s1 (\%13) fen bilimleri, 75'i (\%13) sosyal bilimler, 32'si (\%6) din kültürü ve ahlak bilgisi, 38' i (\%7) sporsanat, 23' ü (\%4) Bilişim teknolojileri, 47’ si (\%8) meslek dersleri, , 70' i (\%12) İngilizce ve 14' ü (\%2) rehberlik şeklindedir.

\section{Verilerin Analizi}

Ölçek geliştirme ve uyarlama çalışmalarında sıklıkla test edilen özelliklerin başında yapı geçerliliği gelmektedir. Yapı geçerliğini test etmek amacıyla sıkça kullanılan yöntemlerden birisi ise faktör analizidir (Büyüköztürk vd., 2014: 119). Bu araştırmada da mesleki gelişim etkinlikleri ölçeğinin yapı geçerliğini test etmek amacıyla AFA ve DFA yapılmıştır. Uyarlama çalışmalarında genellikle DFA analizinin yapılması tercih edilmektedir. Ancak bu çalışmada ölçeğin orijinal formunda yer alan bazı maddeler kültürel olarak uygun olmadığı düşünüldüğünden çıkarılmıştır. Dolayısıyla yapıya ilişkin daha geçerli ve güvenilir analizler yapabilmek için DFA' dan önce AFA' nın yapılmasının uygun olacağı düşünülmüştür. AFA, farklı bileşenlerden oluştuğu için yapısı tam olarak bilinmeyen yapıları ortaya çıkarmak için kullanılan yöntemdir ve ölçek geliştirme çalışmalarında sıklıkla kullanılmaktadır (Can, 2014: 294). DFA ise önceden, tanımlanmış bir yapının, bir model olarak doğrulanıp doğrulanmadığının test edildiği çok değişkenli bir analizdir (Çokluk vd., 2010). Dolayısıyla bu araştırmada öncelikle yapının bileşenlerinin AFA ile ortaya çıarılması ve DFA ile test edilmesi amaçlanmıştır. Ancak AFA ve DFA yapmadan önce verilerin faktör analizinin ön şartlarını sağlayıp sağlamadığının kontrol edilmesi gerekmektedir. Bu ön şartlar verilerin en az aralık ölçeğinde olması, normal dağılım göstermesi, korelasyonların yeterli düzeyde olması, örneklemin homojen olmasıdır (Can, 2014: 298). Bu kapsamda analizin ön şartı olan normallik ve doğrusallık sayıltılarının karşılanabilmesi için veriler gözden geçirilmiş ve bir takım istatistiki analizler yapılmıştır. Histogram ve P-P grafikleri aracıllı̆̆ıla verilerin dağılımı görsel olarak incelenmiştir. Verilere ilişkin z puanları, çarpıklık ve basıklık katsayıları hesaplanmıştır.

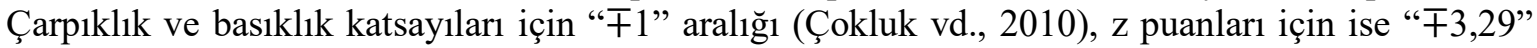
aralığ1 (Field, 2009: 139) dikkate alınmıştır. Bu bağlamda AFA için toplanan verilerden 12'si eksik kodlama, kontrol maddesi, z puanları, çarpıklık ve basıklık katsayıları göz önüne alınarak faktör analizi sürecine girmeden elenmiştir. DFA için toplanan 566 verinin ise bu şartları sağladığı belirlenmiştir. Ayrıca faktör analizi çalışmalarında örneklem büyüklüğünün de önemli olduğu bilinmektedir. Alanyazında örneklem büyüklüğünün asgari olarak 100'ün altında olmaması (Ho, 2006: 207) ve en az madde sayısının 5 katı olması (Çokluk vd., 2010) gerektiği belirtilmektedir. Bu kapsamda değerlendirildiğinde örneklem büyüklüğünün bu şartları sağladığı görülmektedir. Ölçeğin güvenirliğine ilişkin kanıtlar ortaya koyabilmek için Cronbach Alpha iç tutarlılık katsayısı ve maddetoplam korelasyonları (Büyüköztürk, 2010) hesaplanmıştır.

\section{Bulgular}

$\mathrm{Bu}$ bölümde ölçeğin geçerlik ve güvenirlik çalışmalarına ilişkin bulgulara yer verilmiştir.

\section{Mesleki Gelişim Etkinlikleri Ölçeğinin Açımlayıcı Faktör Analizi}

AFA' dan önce, örneklem büyüklüğüyle ilgili bir ölçüt olan Kaiser-Meyer-Olkin (KMO) testi (Can, 2014: 297) yapılarak örneklem büyüklüğünün faktörleştirmeye uygunluğunu test edilmiştir. KMO katsayısı .924 olarak hesaplanmış, Bartlett küresellik testi $(5810.015 ; \mathrm{p}=.000)$ 
anlamlı bulunmuştur. KMO katsayısının .60'dan yüksek olması ve Bartlett testinin anlamlı olması verilerin faktör analizine uygun olduğunun göstergesidir (Büyüköztürk, 2010). Ayrıca KMO katsayısının .90' in üzerinde olması örneklem büyüklüğünün iyi derece yeterli olduğunu göstermektedir (Can, 2014: 303). Ölçeğin yap1 geçerliğini belirleyebilmek için temel bileşenler analizi yapılmıştır. AFA yapılırken, sıklıkla kullanılan dik döndürme tekniklerinden biri olan 'varimax' kullanılmıştır. AFA' da, faktörlerin belirlenmesinde ve ölçek maddelerine ilişkin karar vermede aşağıda belirtilen şu ölçütler (Büyüköztürk, 2010; Çokluk vd., 2010) dikkate alınmıştır:

* Her faktördeki maddelerin anlam ve içerik olarak birbiriyle tutarlı olması,

* Faktör öz değerlerinin 1 ve üzerinde olması,

* Bir maddenin bulunduğu faktördeki faktör yükünün “.40” ve üzeri olmas1,

* Maddelerin bulundukları faktördeki yük değerleri ile diğer faktörlerdeki yük değerleri arasındaki farkın en az ".10" ve daha yukarı olması.

Ölçeğin faktör sayısına karar vermek için öncelikle yamaç-birikinti (scree-plot) eğrisi inelenmiştir. Ölçeğe ilişkin yamaç-birikinti eğrisi şekil 1' de görülmektedir. Faktör sayısına karar vermek için öncelikle yamaç-birikinti eğrisine bakılarak 4 faktörlü yapıya karar verilmiştir.

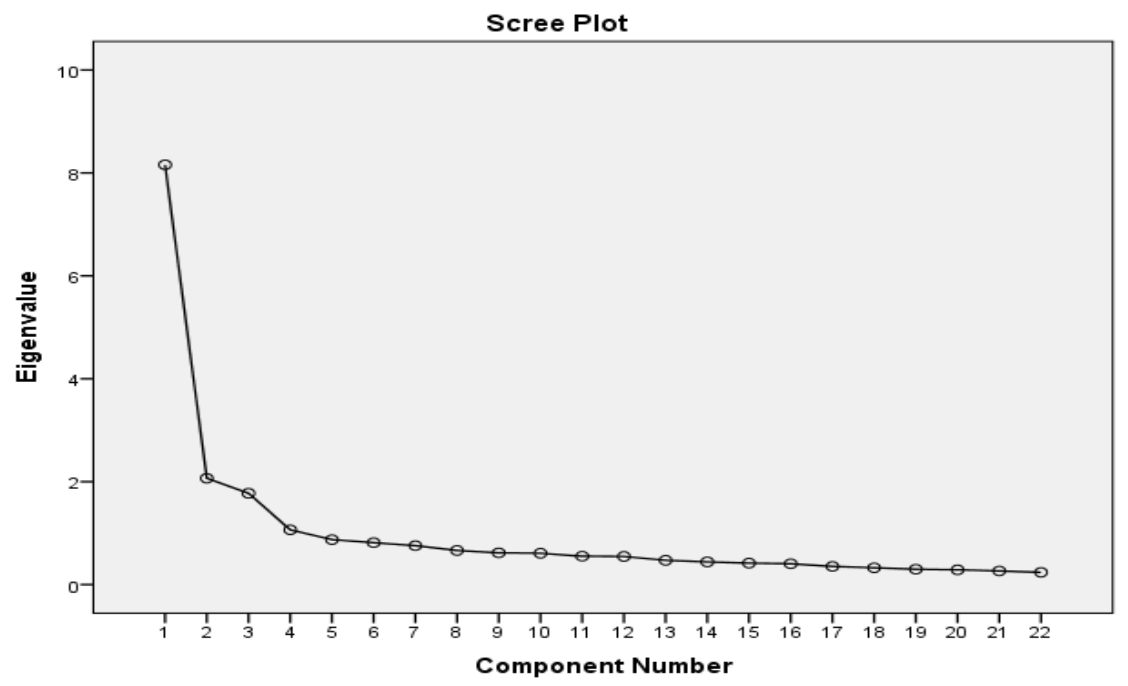

Şekil 1: Mesleki Gelişim Etkinlikleri Ölçeği Yamaç-birikinti Eğrisi

Yapılan AFA sonucunda ölçeğin orijinal formunda bulunan bazı maddelerin $(6,8,9,11,14$, $15,16,17,21,22,23,24,28,31,32,33)$ belirtilen ölçütlere uymadığ belirlenmiştir. Bu maddelerin ölçütlere göre tekrarlanan AFA ile sırayla elenmesinin ardından elde edilen faktörlere ilişkin özdeğerler ve varyans oranları, tablo 2' de görülmektedir.

Tablo 2: Mesleki Gelişim Etkinlikleri Ölçeğinin Açıklanan Varyans Tablosu

\begin{tabular}{cccc}
\hline Faktör & Özdeğer & $\begin{array}{c}\text { Açıklanan } \\
\text { varyans }\end{array}$ & $\begin{array}{c}\text { Toplam } \\
\text { açlklanan } \\
\text { varyans }\end{array}$ \\
\hline $\mathbf{1}$ & 8.158 & 37.08 & 37.08 \\
$\mathbf{2}$ & 2.066 & 9.39 & 46.47 \\
$\mathbf{3}$ & 1.774 & 8.07 & 54.54 \\
$\mathbf{4}$ & 1.064 & 4.84 & 59.37 \\
\hline
\end{tabular}

Turkish Studies - Education, 15(4) 
Tablo 2' de görüldüğü üzere AFA sonucunda belirtilen ölçütleri sağlayan faktörlerden özdeğeri 8.158 olan birinci faktör ölçeğe ilişkin toplam varyansın \%37.08' sini, özdeğeri 2. 066 olan ikinci faktör ölçeğe ilişkin toplam varyansın \%9.39' unu, özdeğeri 1.774 olan üçüncü faktör ölçeğe ilişkin toplam varyansın \%8,07' ini, özdeğeri 1.064 olan dördüncü faktör ölçeğe ilişkin toplam varyansın \%4,84' ünü, açıkladığı görülmektedir. Ölçekte dört faktör tarafindan açılanan toplam varyans ise \%59.37' dir. Ölçme aracı tarafından açıklanan toplam varyansın tek faktörlü ölçeklerde \% 30 ve üzerinde olmasının yeterli olduğu, çok faktörlü ölçeklerde ise bu oranın daha yüksek olması gerekmektedir (Büyüköztürk, 2010). Bu kapsamda değerlendirildiğinde ölçme aracının açıkladığı toplam varyansın (\%59.37) yeterli olduğu söylenebilir.

Analizler sonucunda 22 maddelik 4 boyutlu ölçek elde edilmiştir. AFA' ya ilişkin sonuçlar tablo 3' de verilmiştir.

Tablo 3: Mesleki Gelişim Etkinlikleri Ölçeğinin AFA Sonuçları

\begin{tabular}{|c|c|c|c|c|c|c|}
\hline Maddeler & Faktör 1 & Faktör 2 & Faktör 3 & Faktör 4 & $\begin{array}{l}\text { Faktör } \\
\text { ortak } \\
\text { varyansı }\end{array}$ & $\begin{array}{l}\text { Madde } \\
\text { toplam } \\
\text { korelasyonu }\end{array}$ \\
\hline 20 & ,806 & & & & ,716 &, 833 \\
\hline 22 &, 770 & & & & ,681 & 815 \\
\hline 19 & ,755 & & & & ,675 & 819 \\
\hline 21 & ,716 & & & & ,577 & ,761 \\
\hline 18 & ,700 & & & & ,587 & ,773 \\
\hline 17 & ,634 & & & & ,508 & ,722 \\
\hline 3 & & ,779 & & & ,651 & ,774 \\
\hline 1 & & ,765 & & & ,646 & ,778 \\
\hline 4 & & ,743 & & & ,598 & ,731 \\
\hline 2 & & 697 & & & ,594 & ,740 \\
\hline 6 & & ,591 & & & , 485 & ,700 \\
\hline 5 & & ,591 & & & ,479 & ,666 \\
\hline 7 & & ,491 & & & ,318 & ,611 \\
\hline 12 & & & ,798 & &, 714 & ,819 \\
\hline 14 & & & ,795 & &, 776 & 872 \\
\hline 13 & & & ,777 & &, 714 & 827 \\
\hline 16 & & & 669 & & ,640 &, 813 \\
\hline 15 & & & ,646 & & ,612 & ,802 \\
\hline 11 & & & & ,722 & ,590 & ,744 \\
\hline 10 & & & & ,718 & ,582 & ,739 \\
\hline 9 & & & & 619 & ,498 & ,747 \\
\hline 8 & & & & ,570 & ,422 & ,679 \\
\hline
\end{tabular}

Tablo 3' deki faktör yükleri incelendiğinde birinci faktörde bulunan 6 maddenin $(17,18,19$, $20,21,22)$ faktör yükleri ".634" ile ".806" arasında, madde-toplam korelasyon katsayıları ise ".722" ile ".833" arasındadır. İkinci faktörde bulunan 7 maddenin $(1,2,3,4,5,6,7)$ faktör yükleri ".491" ile ".779" arasında, madde-toplam korelasyon katsayıları ise ".611" ile ".778" arasındadır. Üçüncü faktörde bulunan 5 maddenin $(12,13,14,15,16)$ faktör yükleri ".646" ile ".798" arasında, maddetoplam korelasyon katsayıları ise ".802" ile ".872" arasındadır. Dördüncü faktörde bulunan 4 maddenin $(8,9,10,11)$ faktör yükleri “.570" ile “.722" arasında, madde-toplam korelasyon katsayıları ise ".679” ile “.747” arasındadır. 
Yapılan AFA sonucunda orijinal yapısı 3 boyutlu olan ölçek için 22 maddelik 4 boyutlu bir yapının Türk kültürüne daha uygun olduğu görülmüştür. Faktör analizi sonucu elde edilen faktörler isimlendirilirken, ölçeğin orijinal formundaki isimlendirme, faktörlerde yer alan maddelerin içerikleri ve ilgili literatür göz önünde bulundurulmuştur. Bu dört faktörlü yapının birinci faktöründeki maddeler işbirliği ile ilgili olduğundan "işbirliği etkinlikleri" ikinci faktörde yer alan maddeler akademik okuma ve toplantılara katılımla ilgili olduğundan "güncelleme etkinlikleri", üçüncü faktörde yer alan maddeler paylaşımla ilgili olduğundan "paylaşım etkinlikleri”, dördüncü faktörde yer alan maddeler yansitma ile ilgili olduğundan "yansitma etkinlikleri" olarak adlandırılmıştır.

\section{Mesleki Gelişim Etkinlikleri Ölçeğinin Doğrulayıcı Faktör Analizi}

Mesleki gelişim etkinlikleri için yapılan AFA'nın ardından ölçeğin AFA ile ortaya çıkan yapısının uygunluğunu test etmek DFA yapılmıştır. DFA ile maddelerin temsil güçleri ve her bir maddenin açıkladığı varyans değerlerinin incelenmesi amaçlanmıştır. DFA' da ölçek için elde edilen uyum indeksi değerleri incelenmiştir. Bu uyum değerlendirilirken uyum alanyazında belirtilen uyum indeksi değerleri kullanılmıştır. DFA' da model veri uyumunun değerlendirilmesinde kullanılabilecek ve her biri model uyumu hakkında farklı bilgiler ortaya koyan birçok uyum indeksi vardır. Araştırmacılar genellikle model uyumuna ilişkin daha fazla kanıt ortaya koymak için birden fazla uyum indeksini kullanmaktadır (Harrington, 2009). Yapısal eşitlik modellemesi çalışmalarında en çok tercih edilen uyum indeksleri Ki-kare (Chi-square), NNFI (Non-normed Fit Index), TLI (Tucker-Lewis Index), CFI (Comparative Fit Index), RMSEA (Root Mean Square Error of Approximation), SRMR (Standardized RMR)' dir (Kline, 2011). Bu çalışmada model uyumunu test etmek için yukarıda belirtilen uyum indeksleri kullanılmıştır. Yapılan DFA sonucunda tablo 4' te verilmiş olan uyum indeksi değerleri elde edilmiştir.

Tablo 4: Mesleki Gelişim Etkinlikleri Ölçeğinin DFA Uyum İndeksi Değerleri

\begin{tabular}{lcc} 
İndeks & Modifikasyon öncesi & Modifikasyon sonrasi \\
\hline$\chi^{2}$ & 625.1 & 459,2 \\
$\mathrm{Sd}$ & 203 & 200 \\
$\chi^{2} / \mathrm{sd}$ & 3.08 & 2.297 \\
$\mathrm{NNFI}(\mathrm{TLI})$ & 0.92 & 0.95 \\
$\mathrm{CFI}$ & 0.93 & 0.95 \\
RMSEA & 0.061 & 0.048 \\
RMR & 0.023 & 0.023 \\
SRMR & 0.047 & 0.042 \\
\hline
\end{tabular}

DFA'da elde edilen uyum indeksleri ilgili alanyazın dikkate alınarak değerlendirilmiştir. İlgili alanyazında $\chi^{2} / \mathrm{sd}$ oranının 3' ten küçük olması mükemmel uyumun, 5'ten küçük olması ise iyi uyumun göstergesi olarak değerlendirilmektedir (Kline, 2011). Ayrıca CFI ve TLI uyum değerlerinin $\geq .95$ olması iyi bir uyumun göstergesidir (Hu ve Bentler, 1999; Kline, 2011).Ayrıca RMSEA, SRMR ve RMR değerlerinin .05' in altında olması iyi uyumu, .08'in altında olması ise kabul edilebilir uyumu göstermektedir (Brown, 2006; Kline, 2011; Şimsek, 2007). Birinci DFA' da elde edilen uyum değerleri bu bilgiler 1şığında incelendiğinde, bu değerlerin kabul edilebilir değerler olduğu görülmektedir. Ancak modifikasyon indisleri incelendiğinde bu uyum değerlerini daha iyi hale getirebilecek modifikasyonlar yapılabileceği belirlenmiştir. $\mathrm{Bu}$ aşamadan sonra bu değerleri iyileştirebilmek için şekilde de görülen 3 modifikasyon yapılmıştır. Bu modifikasyonlardan sonra 
elde edilen uyum değerlerinin iyileştiği görülmektedir. Modifikasyondan sonraki DFA'da elde edilen değerler incelendiğinde mevcut değerlerin iyi ve mükemmel uyumu gösterdiği söylenebilir.

Şekil 2' de ölçeğin dört faktörlü modeli ve modelde yer alan faktörler ile o faktörlerde yer alan maddeler arasındaki standardize edilmiş çözümleme değerleri gösterilmektedir. Standardize edilmiş çözümleme değerleri her bir maddenin (gözlenen değişkenin) kendi örtük değişkeninin ne kadar iyi bir temsilcisi olduğuna ilişkin kanıt sunmaktadır (Şimşek, 2007).

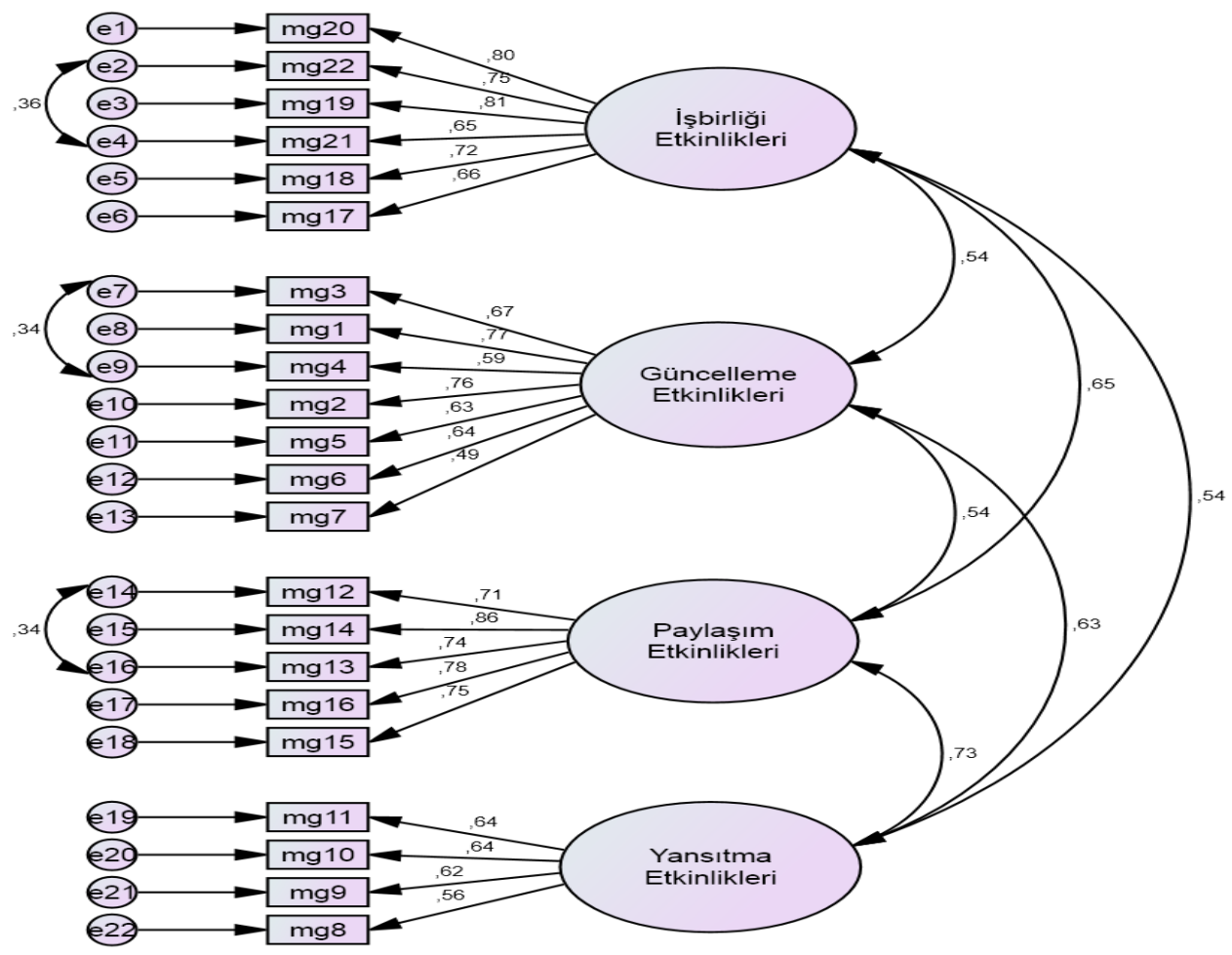

Şekil 2: Mesleki Gelişim Etkinlikleri Ölçeğinin Standardize Edilmiş Çözümleme (Standardized Solution) Değerleri

Şekil 2' de görüldüğü üzere DFA' da elde edilen maddelere ait standardize çözümleme değerleri. 49 ile .86 arasındadır ve tüm faktör-madde ilişkileri. 01 düzeyinde anlamlıdır. Standardize edilmiş çözümleme değerlerinin yüksek olması AFA ile elde edilen yapının uygunluğunu göstermektedir. Bu bulgular ölçme aracının yapısal geçerliğinin sağlandığını göstermektedir.

\section{Mesleki Gelişim Etkinlikleri Ölçeğinin Güvenirlik Analizi}

Ölçeğin güvenirlik analizleri kapsamında güvenirliğin başlıca göstergeleri olan Cronbach Alpha iç tutarlılık katsayısı ve madde-toplam korelasyonları (Büyüköztürk, 2010) hesaplanmıștır. Cronbach Alpha katsayısı ölçek maddelerinin ölçmenin bütünüyle ne kadar tutarlı olduğunu gösterir (Büyüköztürk vd., 2014: 111). Ölçeğin Cronbach Alpha katsayıları, işbirliği etkinlikleri için .88, güncelleme etkinlikleri için .84, paylaşım etkinlikleri için .88, yansıtıcı etkinlikler için, .70 iken ölçeğin geneli için .92 olarak hesaplanmıştır. Ayrıca ölçeğin güvenirlik analizleri kapsamında hesaplanan madde-toplam korelasyonları .443 - .656 arasındadır. Güvenirlik bakımından güvenirlik katsayısının ". $.90 "$ ve üzerinde olması mükemmel güvenirliği, ".80 - $.90 "$ arasında olması çok iyi güvenirliği, “.70- .80” arasında olması yeterli güvenirliği “.50”nin altında olması yetersiz güvenirliği göstermektedir (Kline, 2011). Güvenirlik için madde-toplam korelasyonlarının ise negatif olmaması 
ve .200 üzerinde olması gerekmektedir (Gözüm ve Aksayan, 2003). Dolayısıyla ölçeğin güvenirliğine ilişkin analiz sonuçları güvenirlik için gerekli şartları sağladığı görülmüştür.

\section{Sonuç, Tartışma ve Öneriler}

Öğrenci başarılarının arttırılmasında önemli bir değişken olan öğretmenlerin mesleki gelişimi son yıllarda eğitimin kalitesini arttırmayı amaçlayan eğitim reformlarının, uygulamalarının ve politikalarının temelini oluşturmaktadır (Sandholtz ve Ringstaff, 2013; Smith ve Desimone, 2003). Öğretmenlerin mesleki gelişiminin sağlanması ise mesleki gelişim etkinlikleri yoluyla olmaktadır (İlğan, 2013; Kwakman, 2003). Ancak öğretmenlere bu etkinliklerin sağlanması tek başına yeterli değildir. Çünkü mesleki gelişimin bu etkinlikler yoluyla etkili olabilmesi için ise öncelikle sistematik bir şekilde yürütülmesi gerekmektedir (Guskey, 2000). Bu sürecin sistematik bir şekilde yürütülmesi için ise ölçülesi gerekmektedir. Ancak ilgili alanyazın tarandığında ögretmenlerin mesleki gelişime katılımını ölçecek sınırlı sayıda ölçme aracı olduğu belirlenmiştir. Dolayısıyla öğretmenlerin mesleki gelişim etkinliklerine katılımını ölçecek ölçme araçlarına ihtiyaç duyulmaktadır. Araştırmada bu ihtiyacı karşılamaya yönelik olarak Kwakman (1999) tarafından geliştirilen ve Dijkstra (2009) tarafindan güncellenen mesleki gelişim etkinlikleri ölçeğinin Türk kültürüne uyarlanması amaçlanmıştır.

Ölçeğin uyarlanması aşamasında öncelikle dilsel eşdeğerlik çalışmaları yapılmıştır. Dilsel eşdeğerlik kapsamında maddelerin Türkçeye çevrilmesi ve kültüre uygunluğunu uzman görüşleri doğrultusunda incelenmiştir. Ölçeğin orijinal formunda yer alan 5 madde kültüre uygun olmadığına karar verilerek ölçekten çıkarılmıştır. Uzmanların önerileri doğrultusunda gerekli düzenlemeler yapılarak 35 maddelik deneme formu oluşturulmuş ve örnekleme uygulanmıştır. Elde edilen verilerle yapılan AFA' da varyansın \% 59.37' unu açıklayan 22 maddelik 4 faktörlü bir yapı elde edilmiştir. Yapıya ilişkin elde edilen bulguları destekleyebilmek amacıyla yapılan DFA' daki uyum indeksi değerleri $\left(\chi^{2} / \mathrm{sd}=2.29, \mathrm{CFI}=.95\right.$, TLI $\left.=.95, \mathrm{RMSEA}=.048, \mathrm{RMR}=.023, \mathrm{SRMR}=.042\right)$ iyi uyumu göstermektedir (Brown, 2006; Hu ve Bentler, 1999; Kline, 2011; Şimsek, 2007). DFA ile 4 faktörlü yapısı doğrulanan ölçeğin orjinal formu dikkate alınarak birinci faktörü "işbirliği etkinlikleri”, ikinci faktörü "güncelleme etkinlikleri”, üçüncü faktörü "paylaşım etkinlikleri" ve dördüncü faktörü "yansıtıcı etkinlikler" olarak adlandırılmıştır.

Kwakman (1999) tarafından nitel araştırmayla geliştirilen form 4 faktörlü olmasına rağmen daha sonra Dijkstra (2009) tarafindan pilot uygulaması yapılarak nicelleştirilen formun 3 faktörlü olduğu görülmektedir. Bu farklılıklar ölçme aracının geliştirilmesinde kullanılan yaklaşımların farklılığ 1 ve uygulama tarihleri arasındaki farkl1lıktan kaynaklanabilir. Ancak ölçeğin farklı bir kültüre uyarlandığı bu çalışmada 4 faktörlü bir yapı ortaya çıkmıştır. Uyarlanan bu ölçeğin faktör yapısına benzer bir yapının Liu, Hallinger ve Feng (2016)' in geliştirdiği ve Gümüş ve arkadaşlarının (2018) Türkçeye uyarladığı Öğretmen Mesleki Öğrenme ölçeğinde de ortaya çıktığı görülmektedir. Dört faktör ve toplam 27 maddeden oluşan ölçeğin uyarlanan formunun alt boyutları işbirliği, yansıtma, uygulama ve bilgi tabanına ulaşma şeklinde olup orijinal formuyla tutarlıdır. Bilgi tabanına ulaşma olarak isimlendirilen alt boyutu güncelleme etkinliklerini ifade etmektedir. Bu bağlamda değerlendirildiğinde örneklemleri ve içerikleri benzer olan ölçme araçlarının geçerlik güvenirlik çalışmalarında benzer sonuçlar verdiği görülmektedir. Ölçeğin güvenirlik analizleri kapsamında Cronbach Alpha iç tutarlılık katsayıları, yönetimsel destek için .91, işbirlikçi yapı için .89, yapısal destek için .74 iken ölçeğin geneli için. 92 olarak hesaplanmıştır. Ölçeğin Cronbach Alpha iç tutarlılık katsayılarının yeterli düzeyde olduğu (Kline, 2011) görülmüştür. Ölçeğin madde-toplam korelasyonlarında yeterli olduğu (Gözüm ve Aksayan, 2003) belirlenmiştir. De Vries ve arkadaşları (2013) tarafından bu ölçeğe ilişkin çalışmada ölçeğin güvenilirlik katsayıları Cronbach's Alpha güncelleme etkinlikleri için 0.75 , yansıtıcı etkinlikler için 0.78 , işbirlikçi etkinlikler için 0.86 'dır. Dolayısıyla bu araştırma için hesaplanan iç tutarlılık katsayılarının iyi düzeyde ve orijinal formla uyumlu olduğu belirlenmiş̧ir. 
Türk kültürüne uyarlanan mesleki gelişim etkinlikleri ölçeğinin boyutları işbirliği etkinlikleri, güncelleme etkinlikleri, paylaşım etkinlikleri ve yansıtıcı etkinlikler olarak belirlenmiştir. İşbirliği etkinlikleri öğretmenlerin öğretme ve öğrenmeyi geliştirmek için oluşturduğu grupla işbirlikçi olarak, öğretimsel kararları birlikte aldıkları ve derinlemesine katılımı gerektiren etkinlikleri ifade etmektedir (Kwakman, 2003; Penuel vd., 2007). Öğretmen çalışma gruplarıyla ders planı ve materyali hazırlama, yeni öğretim tekniklerini uygulama gibi etkinlikleri içermektedir (Kwakman, 2003). Güncelleme etkinlikleri, öğretmenlerin daha çok bireysel olarak yapabilecekleri mesleki okuma, güncel gelişmeleri takip etme ve mesleki kurslara katılma gibi etkinlikleri içermektedir (Kwakman, 2003). Paylaşım etkinlikleri öğretmenlerim öğretme-öğrenme sürecindeki deneyimlerine ilişkin görüşlerini ve fikirlerini meslektaşlarıyla paylaştıkları formal veya informal etkinliklerdir (Parise \& Spillane, 2010). Rutin davranışları tanımanın ve değiştirmenin ön şartı olduğu için, yansıtma mesleki gelişimin köşe taşı olarak görülür (Vermunt \& Endedijk, 2011). Yansıtma, öğretmenlerin mesleki gelişimi için olduğu kadar diğer mesleki gelişim grupları içinde oldukça önemlidir (Korthagen, 2017). Yansıtma etkinlikleri, bireysel yansıtmadan kişiler arasındaki güçlü eleştirel diyaloglara kadar bir dizi etkinliği içermektedir (Webster-Wright, 2009). Elde edilen boyutlar birlikte değerlendirildiğinde her bir boyutun farklı mesleki gelişim ihtiyaçlarını karşıladığı söylenebilir. $\mathrm{Bu}$ bağlamda bir öğretmenin bu mesleki gelişim etkinliklerinin hepsine katılması beklenmektedir. Ayrıca etkili mesleki gelişimin kolektif katılım, aktif öğrenme, uyumluluk, etkinlik türünün çeşitliliği, süresinin uzunluğu gibi özellikleri (Garet vd., 2001) dikkate alındığında öğretmenlerin farklı tür mesleki gelişim etkinliklerine katılımı önemlidir.

Sonuç olarak uyarlaması yapılan öğretmenlerin mesleki gelişime katılımlarını ölçebilecek mesleki gelişim etkinlikleri ölçeği 22 maddeden oluşmaktadır. Ölçekte yer alan her bir maddeye ilişkin katılım sıklığını belirlemek için dörtlü likert tipi bir skala kullanılmıştır. Maddelerin puanlanması "hiçbir zaman"=1, "nadiren"= 2, "genellikle" $=3$, her zaman" $=4$ şeklindedir. Ölçekten elde edilebilecek minimum puan 22 , maksimum puan ise $88^{\prime}$ 'dır. Ölçeği puanlama yoluyla elde edilecek yüksek puan, öğretmenlerin mesleki gelişime katılımlarının yüksek olduğunu göstermektedir. Ancak mesleki gelişime katılım düzeyinin yüksek olduğunun söylenebilmesi için her boyuta ilişkin elde edilen puanların yüksek olması beklenmektedir. Çünkü her boyut farklı mesleki bilgi ve becerilerin gelişimini sağlamaktadır. Elde edilen istatistiksel sonuçlar ölçeğin geçerli ve güvenilir olduğunu, öğretmenlerin mesleki gelişime katılımını belirlemek için kullanılabilecek Türk kültürüne uygun bir ölçme aracı olduğunu göstermektedir.

Uyarlanan ölçme aracının bazı sınırlılıkları vardır. Bu sınırlılıkların başında mesleki gelişimde, günümüz dijital öğrenme kaynaklarını ve yöntemlerini vurgulayan maddelerin sınırlı olması gelmektedir. Ancak kuramsal temelleri oldukça sağlam olan bu ölçme aracı öğretmenlerin mesleki gelişime katılımlarının belirlenmesinde, mesleki gelişime katılım ile öğretmen özellikleri ve öğrenci başarısı arasındaki ilişkilerin belirlenmesinde kullanılabilir. Ayrıca mesleki gelişim etkinliğinin türü ile öğretmen uygulamalarına etkisi ve öğrenci başarısına etkisi incelenmesine olanak tanır. Bunun yanında öğretmenlerin mesleki gelişime katılımlarını ölçecek Türk kültürüne özgü ölçme araçlarının geliştirilmesi de oldukça önemlidir.

\section{Kaynakça}

Adesina, O. J., Raimi, S. O., Bolaji, O. A., \& Adesina, A. E. (2016). Teachers' attitude, years of teaching experience and self-efficacy as determinants of teachers' productivity in teachers' professional development programme in Ibadan Metropolis, Oyo State, Nigeria. Journal of Emerging Trends in Educational Research and Policy Studies (JETERAPS), 7(3), 204-211.

Akgündüz, D., Aydeniz, M., Çakmakçı, G., Çavaş, B., Çorlu, M. S., Öner, T., \& Özdemir, S. (2015). STEM eğitimi Türkiye raporu. Scala Basım. https://www.aydin.edu.tr/tr- 
tr/akademik/fakulteler/egitim/Documents/STEM\%20E\%C4\%9Fitimi\%20T\%C3\%BCrkiye \%20Raporu.pdf

Akiba, M., \& Liang, G. (2016). Effects of teacher professional learning activities on student achievement growth. The Journal of Educational Research, 109(1), 99-110. https://doi.org/10.1080/00220671.2014.924470

Baştürk, R. (2012). İlköğretim öğretmenlerinin hizmetiçi eğitime yönelik alg1 ve beklentilerinin incelenmesi. Hacettepe Üniversitesi Ĕ̈itim Fakültesi Dergisi, 42, 96-107.

Bellibaş, M. S., \& Gümüş, E. (2016). Teachers' perceptions of the quantity and quality of professional development activities in Turkey. Cogent education, 3(1), 1-15. https://doi.org/10.1080/2331186X.2016.1172950

Blank, R. K., de las Alas, N., \& Smith, C. (2007). Analysis of the quality of professional development programs for mathematics and science teachers: Findings from a cross-state study. Washington, DC: Council of Chief State School Officers. http://programs.ccsso.org/content/pdfs /Year_2_IMPDE_Fall_06_Rpt_with_errata041708.pdf

Brown, T. A. (2006). Confirmatory factor analysis for applied research. Guilford Press.

Bubb, S., \& Earley, P. (2007). Leading \& managing continuing professional development: Developing people, developing schools. Sage.

Bümen, N. T., Ateş, A., Çakar, E., Ural, G., \& Acar, V. (2012). Türkiye bağlamında öğretmenlerin mesleki gelişimi: sorunlar ve öneriler. Milli Eğitim, Bahar 194, 31-50.

Büyüköztürk, Ş. (2010). Sosyal bilimler için veri analizi el kitabı. Pegem Akademi.

Büyüköztürk, Ş., Çakmak, E. K., Akgün, Ö. E., Karadeniz, Ş., \& Demirel, F. (2014). Bilimsel araştırma yöntemleri (14.bask1). Pegem Akademi.

Caena, F. (2011). Literature review Quality in Teachers' continuing professional development. Education and training, 2020, 2-20. https://pdfs.semanticscholar.org/11c9/e90f3fb8a97e463882d5ab0846b2373279a2.pdf

Can, A. (2014). SPSS ile bilimsel araştırma sürecinde nicel veri analizi (3. bask1). Pegem Akademi.

Chang, J. C., Yeh, Y. M., Chen, S. C., \& Hsiao, H. C. (2011). Taiwanese technical education teachers' professional development: An examination of some critical factors. Teaching and teacher education, 27 (1), 165-173. https://doi.org/ 10.1016 /j.tate.2010.07.013

Craft, A. (2002). Continuing professional development: A practical guide for teachers and schools. Routledge.

Çokluk, Ö., Sekercioglu, G., \& Büyüköztürk, S. (2010). Sosyal bilimler için çok degiskenli istatistik. Pegem Akademi.

Darling-Hammond, L. (2000). Teacher quality and student achievement. Education policy analysis archives, 8(1), 1-44. https://doi.org/10.14507 /epaa. v8n1.2000

de Vries, S., Jansen, E. P., \& van de Grift, W. J. (2013a). Profiling teachers' continuing professional development and the relation with their beliefs about learning and teaching. Teaching and Teacher Education, 33, 78-89. https://doi.org/10.1016/ j.tate.2013.02.006

de Vries, S., Van De Grift, W. J., \& Jansen, E. P. (2013b). Teachers' beliefs and continuing professional development. Journal of Educational Administration, 51(2), 213-231. https://doi.org/10.1108/09578231311304715 
Dijkstra, E. M. (2009). Hoe professioneel is de hedendaagse onderwijsprofessional? [What is the professionality of the contemporary educational professional?]. [Master thesis]. Rijksuniversiteit Groningen

Elçiçek, Z., \&Yaşar, M. (2016). Türkiye'de ve dünyada öğretmenlerin mesleki gelişimi. Elektronik Eğitim Bilimleri Dergisi, 5(9), 12-19.

Eroğlu, M. (2019). Öğretmenlerin mesleki gelişime katılımlarıyla, mesleki gelişsime yönelik tutumlarl, kendi kendine öğrenmeye hazır bulunuşluklarl ve destekleyici okul özellikleri arasındaki ilişkinin incelenmesi [Yayımlanmamış Doktora Tezi]. İnönü Üniversitesi Eğitim Bilimleri Enstitüsü.

Eroğlu, M., \& Özbek, R. (2018). Development of professional development activities scale for teachers. Journal of Current Researches on Social Sciences, 8(3), 185-208.

Field, A. (2009). Discovering statistics using SPSS statistics (Third Edition). Sage.

Garet, M. S., Porter, A. C., Desimone, L., Birman, B. F., \& Yoon, K. S. (2001). What makes professional development effective? Results from a national sample of teachers. American educational research journal, 38(4), 915-945. https://doi.org/10.3102/00028312038004915

Gözüm, S., ve Aksayan, S. (2003). Kültürlerarası ölcek uyarlamasi için rehber II: Psikometrik özellikler ve kültürlerarası karşılaştırma. Hemsirelik Arastirma Gelistirme Dergisi Cilt, 5, 3 14.

Guskey, T. R. (2000). Evaluating professional development. Corwin Press.

Gumus, S. (2013). The effects of teacher-and school-level factors on teachers' participation in professional development activities: The role of principal leadership. Journal of International Education Research, 9(4), 371. https://doi.org/10.19030/jier.v9i4.8089

Gümüş, S., Apaydın, Ç., \& Bellibaş, M. Ş. (2018). Öğretmen Mesleki Öğrenme Ölçeğinin Türkçeye Uyarlanması: Geçerlik ve Güvenirlik Çalışması. Eğitim ve İnsani Bilimler Dergisi: Teori ve Uygulama, 9(17), 107-124.

Hamdan, A. R., \& Lai, C. L. (2015). The relationship between teachers' factors and effective teaching. Asian Social Science, 11(12), 274. http://dx.doi.org/10.5539/ass.v11n12p274

Harrington, D. (2009). Confirmatory factor analysis. Oxford University Press.

Ho, R. (2006). Handbook of univariate and multivariate data analysis and interpretation with SPSS. Chapman and Hall/CRC.

Hu, L. T., \& Bentler, P. M. (1999). Cutoff criteria for fit indexes in covariance structure analysis: Conventional criteria versus new alternatives. Structural equation modeling: $a$ multidisciplinary journal, 6(1), 1-55. https://doi.org/10.1080/10705519909540118

Isabel, L. A. (2010). The effects of high quality professional development activities for teachers on students' Tennessee Comprehensive Assessment Program (TCAP) scores. Tennessee State University.https://search.proquest.com/openview/1a3f288caf5e444299b906d8429753aa/1? pqorigsite $=$ gscholar $\&$ cbl $=18750 \&$ diss $=\mathrm{y}$

İzci, E., \& Eroğlu, M. (2016). Eğitimde teknoloji kullanımı kursu hizmetiçi eğitim programının değerlendirilmesi. International Journal of Human Sciences, 13(1), 1666-1688.

Kaçan, G. (2004). Sınıf öğretmenlerinin mesleki gelişime ilişkin isteklilik düzeyleri. Eskişehir Osmangazi Üniversitesi Sosyal Bilimler Dergisi, 5(1), 57-66. 
Kaya, S., \& Kartallığlu, S. (2010). Okul temelli mesleki gelişim modeline yönelik koordinatör görüşleri. Abant İzzet Baysal Üniversitesi Dergisi, 10 (2), 115-130.

King, M.B. \& Newmann, F.M. (2001). Building school capacity through professional development: Conceptual and empirical considerations. International Journal of Educational Management 15(2), 86-93. https://doi.org/10.1108/095135401 10383818

Kline, R.B. (2011). Principles and practice of structural equation modeling. (3rd edition). New York: Guilford Press.

Korthagen, F. (2017). Inconvenient truths about teacher learning: Towards professional development 3.0. Teachers and teaching, 23(4), 387-405. https://doi.org/10. 1080/13540602.2016.1211523

Kwakman, K. (1999). Leren van docenten tijdens de beroepsloopbaan. [Teacher learning throughout the career]. (Unpublished Doctoral dissertation) University of Nijmegen.

Kwakman, K. (2003). Factors affecting teachers' participation in professional learning activities. Teaching and teacher education, 19(2), 149-170. https://doi.org/ 10.1016/S0742051X(02)00101-4

Lieberman, A. (1995). Practices that support teacher development. Phi delta kappan, 76(8), 591. https://www.nsf.gov/pubs/1995/nsf 95162/nsf_ef.pdf\#page=58

Liu, S., Hallinger, P., \& Feng, D. (2016). Supporting the professional learning of teachers in China: Does principal leadership make a difference?. Teaching and Teacher Education, 59, 79-91. https://doi.org/10.1016/j.tate.2016.05.023

Milli Eğitim Bakanlığı (MEB), (2017). $2023 \quad$ Eğitim Vizyonu. http://2023vizyonu.meb.gov.tr/doc/2023_EGITIM_VIZYONU.pdf

Mizell, H. (2010). Why Professional Development Matters. Learning Forward. 504 South Locust Street, Oxford, OH 45056.

Nye, B., S. Konstantopoulos, \& L. Hedges. 2004. "How large are teacher effects?" Educational Evaluation and Policy Analysis 26 (3): 237-257. https://doi.org/10.3102/01623737026003237

Organisation for Economic Co-operation and Development (OECD), (2005). Teachers matter: Attracting, developing and retaining effective teachers. (Araştırma Raporu), http://www.oecd.org/education/school/34990905.pdf

Organization for Economic Cooperation and Development (OECD). (2011). Building a teaching profession: Lessons from around the World. OECD Publishing.

Özer, B. (2005). Ortaöğretim öğretmenlerinin mesleki gelişime ilgisi. Journal of Educational Sciences \& Practices, 4(8).

Parise, L. M., \& Spillane, J. P. (2010). Teacher learning and instructional change: How formal and on-the-job learning opportunities predict change in elementary school teachers' practice. The elementary school journal, 110(3), 323-346. https://doi.org/10.1086/648981

Penuel, W. R., Fishman, B. J., Yamaguchi, R., \& Gallagher, L. P. (2007). What makes professional development effective? Strategies that foster curriculum implementation. American educational research journal, 44(4), 921-958. https://doi.org/10.3102/0002831207308221

Reese, S. (2010). Bringing effective professional development to educators. Techniques: Connecting Education and Careers (J1), 85(6), 38-43. https://files.eric.ed.gov/fulltext/EJ909588.pdf 
Sandholtz, J. H., \& Ringstaff, C. (2013). Assessing the impact of teacher professional development on science instruction in the early elementary grades in rural US schools. Professional Development in Education, 39(5), 678-697. https://doi.org /10.1080/19415257.2012.751044

Sass, T. R., Hannaway, J., Xu, Z., Figlio, D. N., \& Feng, L. (2012). Value added of teachers in highpoverty schools and lower poverty schools. Journal of urban Economics, 72(2-3), 104-122. https://doi.org/10.1016/j.jue.2012.04.004

Scales, P., Pickering, J., \& Senior, L. (2011). Continuing professional development in the lifelong learning sector. McGraw-Hill Education.

Schön, D. A. (1987). Educating the reflective practitioner. San Francisco, CA: Jossey-Bass.

Seferoğlu, S. S. (2001). Elementary school teachers perceptions of professional development. Hacettepe Üniversitesi Eğitim Fakültesi Dergisi, 20(20), 117-125.

Smith, T. M., \& Desimone, L. M. (2003). Do changes in patterns of participation in teachers' professional development reflect the goals of standards-based reform?. Educational horizons, 81(3), 119-129.

Şimsek, Ö.F. (2007). Yapısal eşitlik modellemesine giris: Temel ilkeler ve LISREL uygulamaları. Ekinoks Basın Yayın Dağıtım Ltd Sti.

Uştu, H., Mentiş-Taş, A., ve Sever, B. (2016). Öğretmenlerin mesleki gelişime yönelik algılarına ilişkin nitel bir araştırma. Elektronik Mesleki Gelişim Ve Araştırmalar Dergisi, 4(1), 82-106.

Vermunt, J. D., \& Endedijk, M. D. (2011). Patterns in teacher learning in different phases of the professional career. Learning and individual differences, 21(3), 294-302. https://doi.org/10.1016/j.lindif.2010.11.019

Webster-Wright, A. (2009). Reframing professional development through understanding authentic professional learning. Review of educational research, 79(2), 702-739. https://doi.org/10.3102/0034654308330970

Wells, M. (2014). Elements of effective and sustainable professional learning. Professional development in education, 40(3), 488-504. https://doi.org/ 10.1080/19415257.2013.838691

Wermke, W. (2013). Development and autonomy: Conceptualising teachers' continuing professional development in different national contexts [Unpublished Doctoral dissertation]. Stockholm University. 
Ek: Mesleki Gelişim Etkinlikleri Ölçeği

\begin{tabular}{|c|c|c|c|c|c|}
\hline \multicolumn{2}{|c|}{$\begin{array}{l}\text { Lütfen her ifadeyi okuduktan sonra size en uygun gelen yanıtı } \\
\text { işaretleyiniz. } \\
\text { "Hiçbir zaman" ifadesi için } \rightarrow 1 \text { '’i } \\
\text { "Nadiren" ifadesi için } \rightarrow 2 \text { 'yi } \\
\text { "Genellikle" ifadesi için } \rightarrow \text { 3'ü } \\
\text { "Her zaman" ifadesi için } \rightarrow \text { 4'ü } \\
\text { *Lütfen hiç bir maddeyi boş bırakmamaya çalışınız. }\end{array}$} & 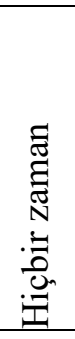 & 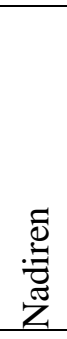 & 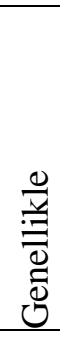 & 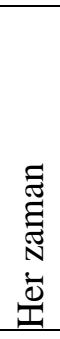 \\
\hline \multirow{7}{*}{ 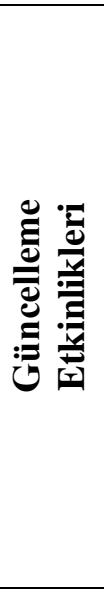 } & $\begin{array}{l}\text { Ulaşabildiğim güncel eserleri/kaynakları okurum (öğretimle } \\
\text { ilgili eserler üzerine broşürlerden, yayınevlerinin web } \\
\text { sitelerinden veya sergi ziyaretlerinden vb) }\end{array}$ & (1) & (2) & (3) & (4) \\
\hline & $\begin{array}{l}\text { Eğitimdeki gelişmeleri ve yenilikleri takip ederim/okurum } \\
\text { (internet, tv, gazete vb. yoluyla). }\end{array}$ & (1) & (2) & (3) & (4) \\
\hline & Mesleğimle ilgili dergileri takip ederim/okurum. & (1) & (2) & (3) & (4) \\
\hline & Bilimsel alan yazını (literatürü) takip ederim/okurum. & (1) & (2) & (3) & (4) \\
\hline & $\begin{array}{l}\text { Branşımla ilgili kaynakları çalışırım/okurum(klavuz kitapları, } \\
\text { ders kitapları, alıştırma kitapları vb). }\end{array}$ & (1) & (2) & (3) & (4) \\
\hline & $\begin{array}{l}\text { Eğitim firsatları/imkanları hakkında bilgi edinirim(broşürlerden, } \\
\text { kurumların web sitelerinden vs). }\end{array}$ & (1) & (2) & (3) & (4) \\
\hline & $\begin{array}{l}\text { Okul dışındaki mesleki gelişim etkinliklerine (kurslar, } \\
\text { çalıştaylar, eğitimler) katılırım. }\end{array}$ & (1) & (2) & (3) & (4) \\
\hline \multirow{4}{*}{ 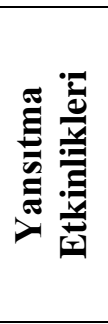 } & Derslerimin verimliliğine ilişkin kendimi değerlendiririm. & (1) & (2) & (3) & (4) \\
\hline & $\begin{array}{l}\text { Meslektaşlarımdan bir şeyler öğrenmek için akran görüş } \\
\text { toplantılarına(örneğin zümre top.) katılırım. }\end{array}$ & (1) & (2) & (3) & (4) \\
\hline & $\begin{array}{l}\text { Öğretim sürecinde karşılaştığım problemi çözmeden önce, iyice } \\
\text { anlamaya/analiz etmeye çalışırım. }\end{array}$ & (1) & (2) & (3) & (4) \\
\hline & $\begin{array}{l}\text { Öğretim performansımı değerlendirmek için öğrencilerimin } \\
\text { ürünlerini (ögrenme çıtıları, ödevler, notlar vb.) incelerim. }\end{array}$ & (1) & (2) & (3) & (4) \\
\hline \multirow{5}{*}{ 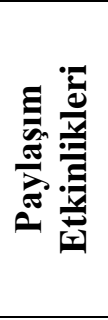 } & Meslektaşlarımla öğretim sorunları üzerine konuşurum. & (1) & (2) & (3) & (4) \\
\hline & Meslektaşlarıma öğretim sorunlarıyla ilgili destek olurum. & (1) & (2) & (3) & (4) \\
\hline & Meslektaşlarımla güncel öğretim/eğitim fikirlerimi paylaşırım. & (1) & (2) & (3) & (4) \\
\hline & $\begin{array}{l}\text { Meslektaşlarımla dersimdeki sorunlarla baş etme stratejilerimi } \\
\text { konuşurum. }\end{array}$ & (1) & (2) & (3) & (4) \\
\hline & $\begin{array}{l}\text { Meslektaşlarımla bana göre eğitimde nelerin önemli olduğunu } \\
\text { konuşurum/tartışırım. }\end{array}$ & (1) & (2) & (3) & (4) \\
\hline \multirow{6}{*}{ 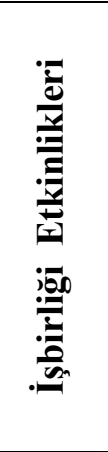 } & $\begin{array}{l}\text { Derslerimde meslektaşlarımın öğretim } \\
\text { materyallerini/dokümanlarını kullanırım. }\end{array}$ & (1) & (2) & (3) & (4) \\
\hline & $\begin{array}{l}\text { Meslektaşlarımla öğretim materyalleri(dijital ve diğer) } \\
\text { geliştiririm. }\end{array}$ & (1) & (2) & (3) & (4) \\
\hline & Meslektaşlarımla birlikte test ve sınav materyalleri geliştiririm. & (1) & (2) & (3) & (4) \\
\hline & $\begin{array}{l}\text { Meslektaşlarımla birlikte öğrenci performans verilerini } \\
\text { incelerim. }\end{array}$ & (1) & (2) & (3) & (4) \\
\hline & Meslektaşlarımla birlikte ders (planı) hazırlarım. & (1) & (2) & (3) & (4) \\
\hline & $\begin{array}{l}\text { Meslektaşlarımla birlikte yeni/farklı öğretim yöntemlerini } \\
\text { denerim. }\end{array}$ & (1) & (2) & (3) & (4) \\
\hline
\end{tabular}

